\title{
Measurements of Taku River, Alaska During Tulsequah Lake Outburst Floods
}

Introduction

Water stored behind, under, or within glaciers can be released rapidly and unexpectedly. These outburst floods can pose a serious threat to life and property. Post and Mayo (1971) identified glacier-dammed lakes in southeastern Alaska and in adjacent areas of Canada, and characterized the potential hazards associated with outburst floods. Tulsequah Lake in Canada (fig. 1) was identified as one of these glacier-dammed lakes with a long history of annual outburst floods.

Tulsequah Lake is at about 1,140 feet above sea level on the north side of Devils Paw Mountain. The lake is impounded by a distributary branch of Tulsequah Glacier and is about 20 miles upstream from the mouth of the Tulsequah River, a major tributary to the Taku River. The U.S. Geological Survey (USGS) has operated a streamflow-gaging station on the Taku River (station No. 15041200) since 1987.

Outburst floods from Tulsequah Lake have occurred frequently and have been documented by Marcus (1960), Miller (1963), Post and Mayo (1971), and the USGS (1988-99) (table 1). Tulsequah Lake is filled during the summer months by rainfall and by glacial melt. As Tulsequah Lake fills, the lake surface rises until the hydrostatic pressure at the base of the ice dam causes the ice to float. As this occurs, water begins flowing near the base of the glacier. This flowing water thermally erodes the dam, progressively enlarging the opening. At Tulsequah Lake, no surface drainage is evident, and all discharge appears to be through a subglacial tunnel. Data from documented outburst floods indicate that the flow of the Taku River generally doubles or triples during a 2- to 3-day period.

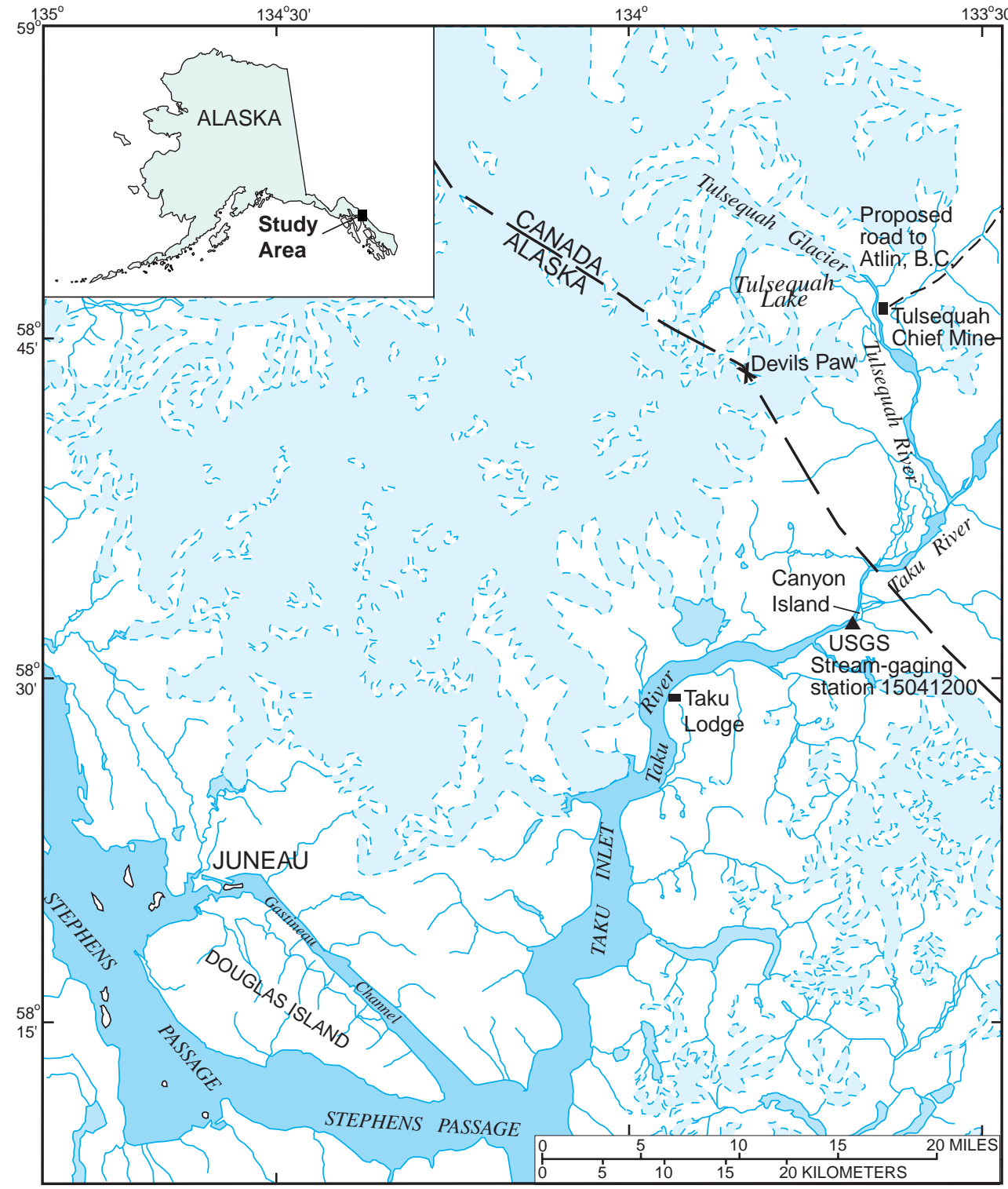

Figure 1. Location of Tulsequah Lake and Glacier and the USGS gaging station on the Taku River, southeast Alaska.

Table 1. Dates of Tulsequah Lake outbursts

\begin{tabular}{|c|c|c|c|c|c|}
\hline Year & Date of outburst & Year & Date of outburst & Year & Date of outburst \\
\hline 1998 & July $31-$ August 3 & 1987 & August $25-28$ & 1948 & July $23-27$ \\
\hline 1997 & July $25-28$ & 1958 & July $7-10$ & 1947 & August 5-9 \\
\hline 1996 & September $17-20$ & 1957 & August $13-16$ & 1946 & August 4-8 \\
\hline 1995 & July $24-27$ & 1956 & August 29-September 1 & 1945 & August 8-11 \\
\hline 1994 & July 28-August 1 & 1955 & September 4-7 & 1944 & August 15-19 \\
\hline 1993 & July 26-29 & 1954 & September $11-14$ & 1943 & July \\
\hline 1992 & August 18-21 & 1953 & July 6-10 & 1942 & July \\
\hline 1991 & August $30-$ September 2 & 1952 & August 6-9 & 1932 & August 15-20 \\
\hline 1990 & July $18-21$ & 1951 & July 26-29 & 1926 & January \\
\hline 1989 & August 14-18 & 1950 & July $27-30$ & 1910 & Summer \\
\hline 1988 & July $31-$ August 2 & 1949 & August 7-10 & & \\
\hline
\end{tabular}




\section{Tulsequah Lake Outburst Flood}

An outburst flood from Tulsequah Lake was documented on the Taku River during July 25-28, 1997. USGS personnel from Juneau measured the discharge, stage, and temperature of the water surface at the gaging station on the Taku River. For the first time since the gaging station was established in 1987, measurements were made at the actual time of an outburst flood. Four measurements were made while flood stage and discharge were increasing, one measurement was made during the peak discharge, and three measurements were made while stage and discharge were decreasing (fig. 2). The prebreakout discharge was about 35,000 cubic feet per second on July 24 , and the peak discharge was about 70,000 cubic feet per second.

An Acoustical Doppler Current Profiler (ADCP) was used to measure the discharge during the 1997 outburst flood. The ADCP is an improved method of making high-quality discharge measurements (Morlock, 1996). Discharge measurements made with the ADCP take less time, are safer, and have smaller errors than those made by conventional methods. The decreased time required for measuring the discharge is important for making highquality measurements during a rapidly changing stage. Furthermore, the positiontracking capability of the ADCP permits the measurements to be made without need for a cable across the flood path and allows the boat to be maneuvered to avoid debris carried by the river during the flood.

The ADCP also recorded temperatures of the water surface during the eight discharge measurements. Water temperature of the Taku River decreased as Tulsequah Lake drained (table 2) and then increased slightly_-but not uniformly across the river - during the peak of the outburst flood. Temperature continued to increase and become more uniform as the water discharge decreased. This temperature distribution probably indicates that the Taku River waters were not well mixed and that cooler outburst waters were concentrated on the north side of the river. The length of river that is incompletely mixed appears to extend as far as the gaging station, 8.5 miles downstream from the confluence of the Tulsequah and Taku Rivers. A similar temperature distribution was observed in the 1998 flood, during which the peak discharge was 69,000 cubic feet per second.
Table 2. Water temperature of the Taku River, July 25-28, 1997

\begin{tabular}{crll}
\hline \multirow{2}{*}{$\begin{array}{c}\text { Date } \\
\text { July } 1997\end{array}$} & Time & \multicolumn{2}{c}{$\begin{array}{c}\text { Water temperature } \\
\text { (degrees Celsius) }\end{array}$} \\
\cline { 3 - 4 } & & $\begin{array}{c}\text { South } \\
\text { bank }\end{array}$ & $\begin{array}{c}\text { North } \\
\text { bank }\end{array}$ \\
\hline 25 & 9:29 p.m. & 8 & 8 \\
26 & 11:02 a.m. & 5.5 & 4.5 \\
& 8:03 p.m. & 7 & 4.5 \\
27 & 6:57 a.m. & 6 & 2.5 \\
& 2:36 p.m. & 8.5 & 4.5 \\
& 7:11 p.m. & 9.5 & 6 \\
& 10:27 p.m. & 8 & 7.5 \\
& 1:37 p.m. & 8.5 & 8.5 \\
\hline
\end{tabular}

\section{Flood Hazards}

The annual glacier outburst of Tulsequah Lake is a potentially dangerous and destructive flood that may affect inhabitants of the Taku and Tulsequah River Valleys. As this area becomes developed, the frequency and magnitude of outburst floods are of great concern.

The Tulsequah Chief Mine (fig. 1) is approximately 18.5 miles upstream from the Alaska-Canada border in the Tulsequah River Valley. Recently, the Canadian government has approved permits to reactivate the mine and build a 100-mile-long road to access the mine from Atlin, British Columbia. Outburst floods could damage the mine and road. About 40 cabins have been built along both banks of the river near the USGS stream-gaging station. In addition, increased tourism routinely brings visitors to the Taku River and Taku Lodge by boat and floatplane during the summer months. The floodwaters and debris released during the outburst floods can threaten the safety of tourists and have negative consequences on the fishing industry in Taku Inlet. Deposits of debris and sediments associated with the outburst may dramatically change the river channel during and after the Tulsequah Lake outburst floods. These channel changes create potentially hazardous conditions for an unknowing boat operator or floatplane pilot.

Understanding how rivers can rise unexpectedly and rapidly during an outburst flood improves the ability to identify possible downstream hazards and increases awareness. Understanding how discharge and water temperature vary during an outburst flood allows a better comprehension of the physical processes that released the water, which improves definition of downstream hazards and water quality.

\section{References Cited}

Marcus, M.G., 1960, Periodic drainage of glacier-dammed Tulsequah Lake, British Columbia: Geographical Review, v. 50, p. 89-106.

Miller, M.M., 1963, Taku Glacier evaluation study: State of Alaska Department of Highways, 200 p.

Morlock, S.E., 1996, Evaluation of acoustic Doppler current profiler measurements of river discharge: U.S. Geological Survey Water-Resources Investigations Report 95-4218, $37 \mathrm{p}$.

Post, Austin, and Mayo, L.R., 1971, Glacierdammed lakes and outburst floods in Alaska: U.S. Geological Survey Hydrologic Atlas HA-455, 10 p., 3 pl.

U.S. Geological Survey, 1988-99, Water resources data for Alaska-water years 1987-98: U.S. Geological Survey WaterData Reports AK-87-1 to AK-98-1 (published annually).

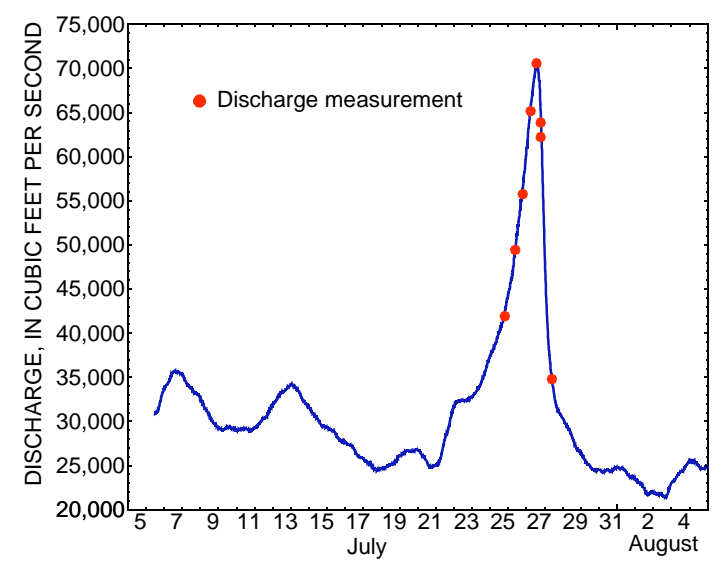

Figure 2. Discharge in the Taku River from July 5 to August 5, 1997. Tulsequah Lake outburst flood was on July $25-27$. -by Randy H. Host and Joseph M. Dorava

For more information, please contact:

U.S. Geological Survey 4230 University Dr. Anchorage, AK 99508-4664 907-786-7100 http://ak.water.usgs.gov 